\title{
RESISTENSI OBAT MALARIA: MEKANISME DAN PERAN OBAT KOMBINASI OBAT ANTIMALARIA UNTUK MENCEGAH
}

\section{ANTIMALARIAL DRUG RESISTANCE: MECHANISM AND THE ROLE OF DRUG COMBINATION IN PREVENTING IT}

\author{
Dorta Simamora *, Loeki Enggar Fitri ** \\ ${ }^{*}$ Biologi Fakultas MIPA Universitas Satya Wyata Mandala (USWIM) Nabire-Papua \\ ** Laboratorium Parasitologi Fakultas Kedokteran Universitas Brawijaya Malang
}

\begin{abstract}
Multi drug resistance (MDR) of malariae parasite is caused by decreasing ability of some antimalarial drugs examples chloroquine, mefloquine, antifolate and atovaquone to Plasmodium. Resistance to artemisin has not been found yet. Antimalaria drug resistance happened because some factors especially : genetic factor (gene mutation) of the Plasmodium. Mechanism pathway of resistance differs in location, because the different target drug action. Resistance migh be reduce by using combination therapy.

Key words : resistance, Plasmodium falciparum, antimalaria combination
\end{abstract}

\section{PENDAHULUAN}

Resistensi obat malaria adalah kemampuan dari parasit untuk terus hidup dalam tubuh manusia, berkembang biak dan menimbulkan gejala penyakit meskipun telah diberikan pengobatan secara teratur baik dengan dosis standart maupun dengan dosis yang lebih tinggi yang masih bisa ditolerir oleh pemakai obat (1). Dalam konteks malaria dikenal Multidrug resistant (MDR) yaitu resistensi terhadap lebih dari satu jenis obat antimalaria, yang sehari-hari dipakai dalam pengobatan malaria. MDR merupakan fenomena resistensi Plasmodium terhadap obat antimalaria serta perlu diperhatikan.

Resistensi parasit Plasmodium falciparum terhadap obat-obatan merupakan masalah di daerah endemik. Di wilayah-wilayah endemik ini, peningkatan resistensi parasit terhadap obat-obatan yang ada merupakan salah satu penyebab tingginya angka morbiditas dan mortalitas akibat malaria (2). Penyebab resistensi terutama adalah karena adanya mutasi pada gen-gen dari Plasmodium (3). Ada tiga faktor yang mempengaruhi kecepatan terjadinya resistensi. Faktor tersebut adalah pertama: faktor operasional misalnya dosis subterapik, kepatuhan inang yang kurang, kedua: faktor farmakologik dan ketiga adalah faktor transmisi malaria, termasuk intensitas, drug pressure dan respon imun inang (4).

Mutasi gen parasit berkaitan dengan target obat, karena dapat mempengaruhi konsentrasi obat intraparasitik. Dalam percobaan resistensi secara in vitro mutasi gen pada parasit mempunyai hubungan dengan marker molekuler

Jurnal Kedokteran Brawijaya,Vol. XXIII, No. 2, Agustus 2007 Korespondensi: Simamora; Biologi FMIPA Univ. Satya Wyata Mandala (USWIM) Nabire-Papua. pada uji klinis. Mutasinya multipel, sangat kompleks dan terjadi secara terus menerus (5).

Parasit $P$. falciparum mempunyai kecenderungan menjadi resisten terhadap obat antimalaria dibandingkan spesies yang lain (6). Untuk mencegah atau untuk memperlambat laju resistensi, WHO menganjurkan agar penderita malaria menggunakan terapi kombinasi antimalaria (7). Bagaimana mekanisme terjadinya resistensi obat antimalaria dan bagaimana kombinasi obat antimalaria dapat menghambat terjadinya resistensi akan dibahas dalam tulisan ini.

\section{Penggolongan Obat Antimalaria}

Obat antimalaria dapat dikelompokkan menurut efek atau cara kerja obat pada parasit stadium eritrositik. Beberapa mekanisme kerja dan target dari obat malaria yang telah diteliti oleh peneliti-peneliti pendahulu, antara lain:

1). Gangguan pencernaan hemoglobin dalam lisosom vakuola makanan (food vacuola) parasit. Obat golongan 4-aminokuinolin sangat esensial dalam mengganggu proses pencernaan hemoglobin oleh parasit dengan jalan mengadakan interaksi dengan heme atau menghambat pembentukan hemozoin. Target baru obat golongan ini adalah menghambat enzim plasmepsin dan enzim falcipain yang berperan dalam pemecahan globin menjadi asamasam amino. Hemozoin dan asam asam amino diperlukan untuk pertumbuhan parasit, sehingga jika pembentukan dihambat maka parasit akan mati.

2). Gangguan pada jalur folat dalam sitoplasma parasit. Obat antimalaria Sulfadoxine Pyrimethamine (SP) dan kombinasi baru chlorproguanil-dapsone (Lapdap) merupakan inhibitor kompetitif yang berperan dalam jalur folat. 
3). Pengantar proses alkilasi. Generasi obat dari artemisin menghasilkan radikal bebas yang berfungsi untuk mengalkilasi membran parasit.

4). Fungsi mitokondria. Mitokondria merupakan target obat baru yang potensial. Kerja Atovaquone melalui penghambatan reduktase sitokrom $\mathrm{c}$ menjadi dasar bersinergi dengan obat-obatan proguanil.

5). Apikoplas. Kerja obat antibiotik tetrasiklin di dalam apikoplast adalah dengan mengganggu translasi protein (8)

Tabel 1. Target dan Komponen Aktif dari Antimalaria (9)

\begin{tabular}{|c|c|c|c|c|c|}
\hline & & & Cont & & \\
\hline Lokasi Target & Jalur Mekanisme & Molekul Target & Terapi yang Ada & Komponen Baru & Referensi \\
\hline sitosol & metabolisme folat & Dihydrofolate reductase & Pyrimethamine, proguanil & Chorproguanil & $\begin{array}{l}\text { Nzila et al., 2000; } \\
\text { Mutabingwa et al., } 2001\end{array}$ \\
\hline & glycolysis & $\begin{array}{l}\text { dihydropteroate synthase } \\
\text { Thymidylate synthase } \\
\text { lactate dehydrogenase }\end{array}$ & sulfadoxine, dapsone & $\begin{array}{l}\text { 5-fluoroorotate } \\
\text { gossypol derivats }\end{array}$ & $\begin{array}{l}\text { Rahod et al., } 1992 \\
\text { Razakantoanina et al., } 2000\end{array}$ \\
\hline $\begin{array}{l}\text { membran } \\
\text { parasit }\end{array}$ & $\begin{array}{l}\text { Phospholipid synthesis } \\
\text { transport membran }\end{array}$ & $\begin{array}{l}\text { choline transporter } \\
\text { unique channels }\end{array}$ & & $\begin{array}{l}\text { G25 } \\
\text { dinucleoside dimers }\end{array}$ & $\begin{array}{l}\text { Wengelnik et al., } 2002 \\
\text { Gero et al., } 2003\end{array}$ \\
\hline vakuola & heme polymerization & Hemozoin & quinolines & New quinolines & De et al., 1998; \\
\hline & hemoglobin hydrolysis & Plasmepsins & & Protease inhibitors & $\begin{array}{l}\text { Stocks et al., } 2002 \\
\text { Francis et al., 1994; } \\
\text { Haque et al., } 1999\end{array}$ \\
\hline & & Falcipains & & Protease inhibitors & $\begin{array}{l}\text { Rosenthal, } 2001 \mathrm{~b} ; \\
\text { Shenai et al., } 2003\end{array}$ \\
\hline & $\begin{array}{l}\text { Pembentukan radikal } \\
\text { bebas }\end{array}$ & unknown & artemisinin & New peroxides & $\begin{array}{l}\text { Vennersstrom et al., 2000; } \\
\text { Borsnik et al., } 2002\end{array}$ \\
\hline mitokondria & transport elektron & Cyt. C Oxidoreductase & atovaquone & & \\
\hline apikoplas & Protein synhesis & Apikoplast ribosom & antibiotics & & \\
\hline & DNA synthesis & DNA gyrase & quinolones & & \\
\hline & Transkripsi & RNA polymerase & Rifampin & & \\
\hline & $\begin{array}{l}\text { Tipe II fatty acic } \\
\text { biosynthesis }\end{array}$ & $\mathrm{FabH}$ & & Thiolactomycin & Waller et al., 1998 \\
\hline & & Fabl & & Triclosan & Surolia and surolia, 2001 \\
\hline & Isoprenoid synthesis & DOXP reductoisomerase & & Fosmidomycin & Jomaa et al., 1999 \\
\hline & Protein farnesylation & Farnesyl transferase & & Peptidomimetics & $\begin{array}{l}\text { Ohkanda et al., 2001; } \\
\text { Chacrabarti et al., } 2002\end{array}$ \\
\hline
\end{tabular}

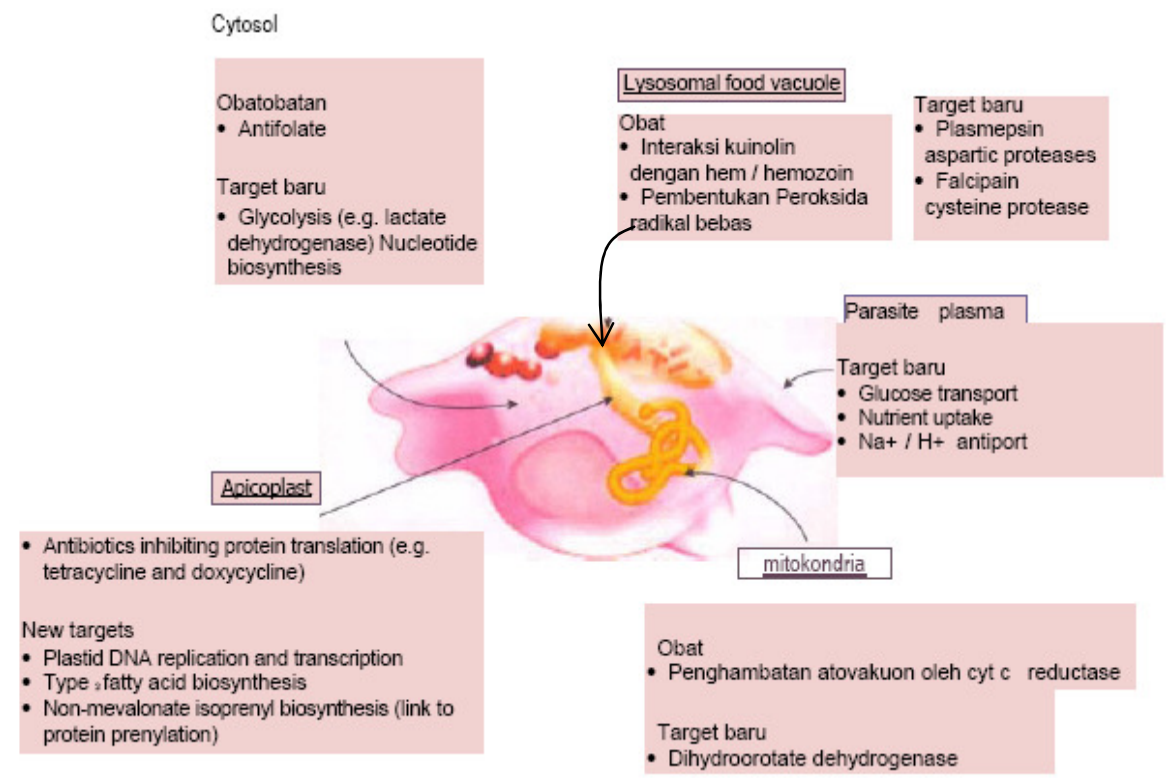

Gambar 1. Lokasi, Kerja dan Target Kerja Baru dari Obat Antimalaria (Ridley, 2002) (10). Diagram Eritrosit yang Terinfeksi $P$. falciparum pada Fase Trofozoit . Organel-organel Utama Terhubung dengan Lokasi Kerja Obat dan Target-Baru dari Obat Antimalaria (Foster, 1991) (11). 


\section{Cara Kerja dan Mekanisme dan Mekanisme Resistensi 1. Klorokuin (Chloroquine /CQ)}

Efektifitas $C Q$ terbatas pada saat parasit malaria berada dalam tahap eritrositik. Beberapa fakta menunjukkan bahwa $C Q$ bekerja di dalam FV dari parasit $(12,13)$. Degradasi hemoglobin0 pada FV menghasilkan heme sebagai produk. Pada parasit terdapat enzim yang penting diantaranya adalah aspartic protease dikenal dengan plasmepsin yang secara in vitro maupun in vivo berperan untuk menginisiasi degradasi hemoglobin (14). (15) Kublin et al., (2003) menyatakan bahwa CQ bekerja dengan mengikat cincin feriprotoporfirin $I X$ suatu hematin yang merupakan hasil metabolisme hemoglobin didalam parasit. Ikatan feriprotofirin $I X$ dari $C Q$ ini bersifat melisiskan membran parasit sehingga mati (15). Konsentrasi sitotoksik dari $C Q$ pada vakuola dapat menghambat pembentukan hemozoin pada eritrosit (16).

Penyebaran galur $P$. falciparum menyebabkan level resistensi parasit terhadap $C Q$ menjadi tinggi, walaupun demikian sampai sekarang $C Q$ masih digunakan di beberapa tempat di dunia (8).

Pada umumnya bila resistensi terhadap suatu obat antimalaria sudah terjadi akan diikuti dengan resistensi terhadap obat antimalaria lainnya. Diduga mekanisme resistensi terhadap $C Q$ sama dengan obat antimalaria yang lain. Tekanan obat yang terus menerus menyebabkan parasit akan memasuki jalur metabolisme yang lain dan menyebabkan terjadinya mutasi. Dengan demikian parasit terhindar dari pengaruh obat. Hal inilah yang menyebabkan resistensi parasit terhadap obat antimalaria terjadi secara perlahan-lahan (17).

Dikatakan resistensi parasit terhadap $\mathrm{CQ}$ pada manusia, disebabkan adanya penurunan akumulasi obat pada pencernaan parasit di vakuola, terutama karena $\mathrm{pH}$ di kompartemennya berubah menjadi asam (18), namun Kirk mengemukakan suatu studi terbaru tentang galur $P$. falciparum yang sensitif dan yang resisten terhadap $C Q$ dengan menggunakan dextran linked $\mathrm{pH}$ sensitive fluorescent dyes. Estimasi konsentrasi dan tekanan serta perubahan pada pencernaan di vakuola memiliki $\mathrm{pH}$ yang bervariasi berkisar antara 3.7-6.5. Ternyata konsentrasi dye pada pencernaan di vakuola rendah, yaitu pHnya berkisar antara $4.5-4.9$, baik pada parasit yang resisten maupun yang sensitif terhadap CQ $(18,19,20)$.

Resistensi $P$. falciparum terhadap $C Q$ terjadi secara spontan (21). Resistensi $P$. falciparum terhadap $C Q$ bersifat multigenik karena mutasi terjadi pada gen yang mengkode plasmodium falciparum chloroquine resistant transporter (pfcrt) transporter pertama dan plasmodium falciparum multidrug resistant (pfmdr-1) transporter kedua $(5,22)$. Sejumlah laporan penelitian terbaru memprediksi bahwa resistensi parasit terhadap $\mathrm{CQ}$ terjadi karena adanya peningkatan pada pfcrt dan pfmdr-1. Pfmdr-1 merupakan kontributor utama parasit menjadi resisten terhadap CQ (5). Melalui percobaan secara in vitro kedua transporter tersebut terkait dengan tingkat resistensi. Di Malawi penggunaan $C Q$ sudah dihentikan sejak 1993 karena prevalensi dari pfcrt mengalami penurunan dari $85 \%$ (1992) menjadi 13\% (2000) (8).

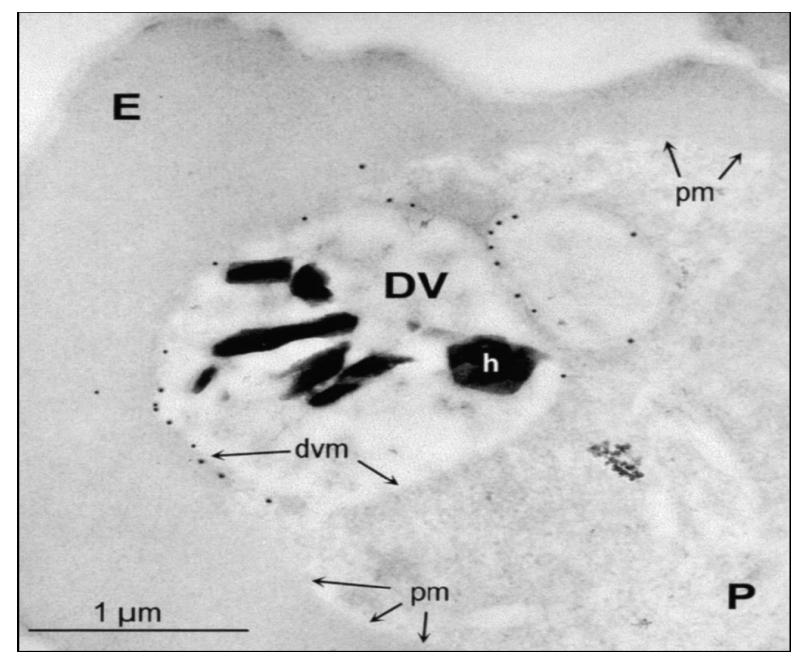

Gambar 2.Lokalisasi protein pfcrt melalui mikroskop imunoelektron (Cooper, 2002) (23).

Keterangan:

Pada Gambar 2 tampak eritrosit berparasit setelah pemberian antibody poliklonal pada pfcrt pada membran digestive vakuola yang dilabel emas anti lgG kelinci. Partikel emas pada Pfcrt terlokalisasi pada membran digestive vakuola pada parasit tahap tropozoit. P, parasit; $\mathbf{E}$, eritrosit; $\mathbf{h}$, hemozoin; $\mathbf{d v m}$, digestive vacuole membrane; pm, parasite membrane (23).

\section{Meflokuin}

Meflokuin adalah obat antimalaria golongan 4-metanol kuinolin. Mekanisme kerja meflokuin sama dengan kloroquin. Meflokuin bersifat skizontosida darah untuk ke 4 spesies Plasmodium manusia dan galur $P$. falciparum yang $M D R$, dosis yang dianjurkan adalah $15-29 \mathrm{mg} / \mathrm{kgbb}$, peroral, dosis tunggal atau terbagi dalam 2 dosis tiap 12 jam. Obat ini tidak diberikan pada wanita hamil trimester pertama (25). Pada penelitian pengobatan dengan pemberian meflokuin pada penderita malaria falciparum dengan atau tanpa komplikasi menunjukkan bahwa meflokuin efektif dan aman (8).

Resistensi $P$. falciparum terhadap meflokuin dan arylaminoalkohol terkait dengan amplifikasi (yaitu duplikasi, bukan mutasi) pada Pfmdr yang mengkode pompa glikoprotein-p (Pgh) dan membutuhkan energi (18). Faktor genetik yang beragam mempunyai konsekuensi terhadap berkurangnya konsentrasi intraseluler dari kuinolin. Dengan demikian pemberian antimalaria kuinolin dapat mempengaruhi penurunan kemampuan dari parasit untuk mendetoksifikasi heme yang dikeluarkan oleh hemoglobin (8). 
Nishiyama melaporkan bahwa resistensi terhadap golongan kuinolin terjadi karena keterlibatan gen MDR dan familinya (26). Analisis molekuler gen pfmdr-1 yang diisolasi dari $P$. falciparum, 523a $\mathrm{R}$ dari Jepang, menunjukkan bahwa pfmdr-1 mempunyai alela yang transgenik dari galur $P$. falciparum sehingga menyebabkan resisten terhadap meflokuin dan beberapa antimalaria lain. Pada analisis DNA urutan gen pfmdr1 yang bergabung pada galur alela intragenik resisten terhadap meflokuin. Ekspresi mRNA pfmdr1 yang berlebihan menyebabkan mekanisme resisten mefloquin menjadi 7,2 kali lebih tinggi (27).

\section{Obat-obat yang Mengganggu Jalur Folat Parasit}

Resistensi $P$. falciparum dan $P$. vivax, terhadap antifolat (pyrimethamin dan cylcloguanil) dihasilkan dari akusisi sekuensial mutasi pada gen dihydrofolate reduktase (dhfr) (22). Mutasi juga menyebabkan terjadinya penurunan terhadap kerentanan. Resistensi parasit terhadap sulfona-
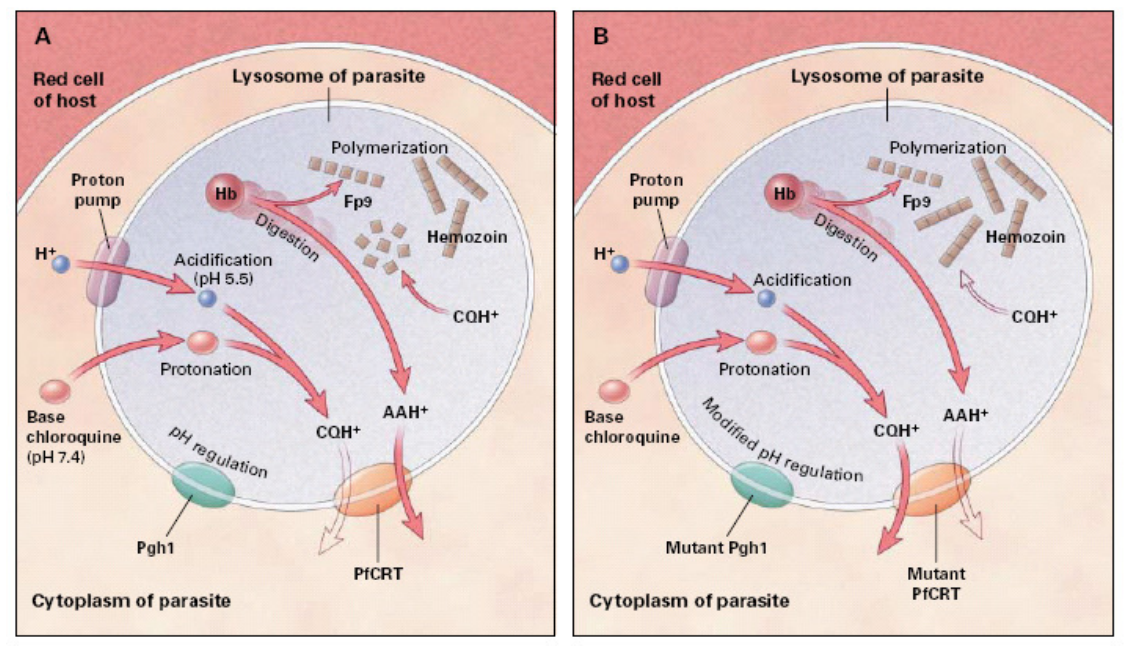

Gambar 3. Mekanisme Resistensi Parasit terhadap Klorokuin (CQ) (24) sinthase dihidropteroate. utama pada jalur folat (8).

mida dan sulfone yang dikombinasikan dengan antifolate menghasilkan mutasi akuisisi sekuensial pada gen dihydropteroate synthase (dhps) yang mengkode enzim

Reaksi yang ditimbulkan dari obat golongan antifolate sangat luas sehingga dapat mengganggu sintesa DNA melalui deplesi pada tetrahydrofolate dan merupakan kofaktor yang penting pada jalur folat. Ada dua jalur penting yang terkait, yaitu (i). sebagai kompetitif inhibitor pada enzim dihydrofolate reduktase (DHFR). Kelompok tersebut antara lain pyrimethamine dan biguanides proguanil serta chlorproguanil (keduanya dibutuhkan pada biotransformasi untuk triazines cycloguanil dan chlorcycloguanil pada enzim DHFR; (ii). sebagai kompetitif inhibitor dari enzim dihydropteroate synthase (DHPS) menjadi enzim yang

Keterangan:

Ion hidrogen masuk melalui pompa proton dan mengasamkan lingkungan lisosom (pH 5.5) diduga proses tersebut diatur oleh protein Pgh 1, dengan melepaskan anion ke lisosom untuk mengoptimalkan perbedaan muatan transmembran. Selama pencernaan hemoglobin $(\mathrm{Hb})$, Ferriprotoporphyrin IX didetoksifikasi melalui polimerisasi dan membentuk kristal pada hemozoin. CQ yang terdapat pada sitoplasma menjadi lemah ( $\mathrm{pH}$ 7.4), sehingga lingkungan pada membran lisosom menjadi asam. Pada kondisi tersebut terjadi protonasi membentuk $\left(\mathrm{CQH}^{+}\right)$yang tidak dapat larut dalam membran sehingga terkonsentrasi dengan cepat. $\mathrm{CQH}^{+}$yang terikat dengan ferriprotoporphrrin IX akan menghambat terjadinya polimerisasi. Ferriprotoporphyrin IX yang terakumulasi akan menyebabkan kerusakan pada membran. Lisosom akan mengeluarkan Asam amino yang diprotonasi melalui beberapa protein transmembran misalnya PfCRT. Protein PfCRT memiliki afinitas yang terbatas untuk $\mathrm{CQH}^{+}$sehingga menyebabkan parasit menjadi sensitif terhadap CQ (Gambar 3A). Parasit malaria yang resisten terhadap CQ. Menunjukkan mutasi pfcrt dan pfmdr-1 pada lisosom berhubungan dengan resistensi parasit terhadap CQ. Diduga Mutan PfCRT mengalami peningkatan affinitas pada $\mathrm{CQH}^{+}$dan melepaskan sejumlah besar obat, sehingga memungkinkan terjadinya polimerisasi ferriprotoporphyrin IX, pada kondisi normal secara bersamaan, akan menyebabkan penurunan affinitas $\mathrm{AAH}^{+}$pada mutan PfCRT, sehingga efisiensi eksport $\mathrm{AAH}^{+}$akan berkurang dan menyebabkan terhapusnya $\mathrm{CQ}$, selanjutnya akumulasi proton pada lisosom menjadi lebih banyak $\left(\mathrm{H}^{+}\right)$. Adanya mutan Pgh 1 yang secara parsial diduga dapat mencegah terjadinya akumulasi pada proton, dengan demikian parasit akan mengalami mutasi pada pfort dan pfmdr 1. Mutasi gen pfmdr 1 ini dapat meningkatkan sensitivitas parasit terhadap mefloquine dan artemisinin, hal ini diduga sebagai akibat ketidak aktifan parsial mutan Pgh1 untuk mengekspor obat tersebut (Gambar 3B). 


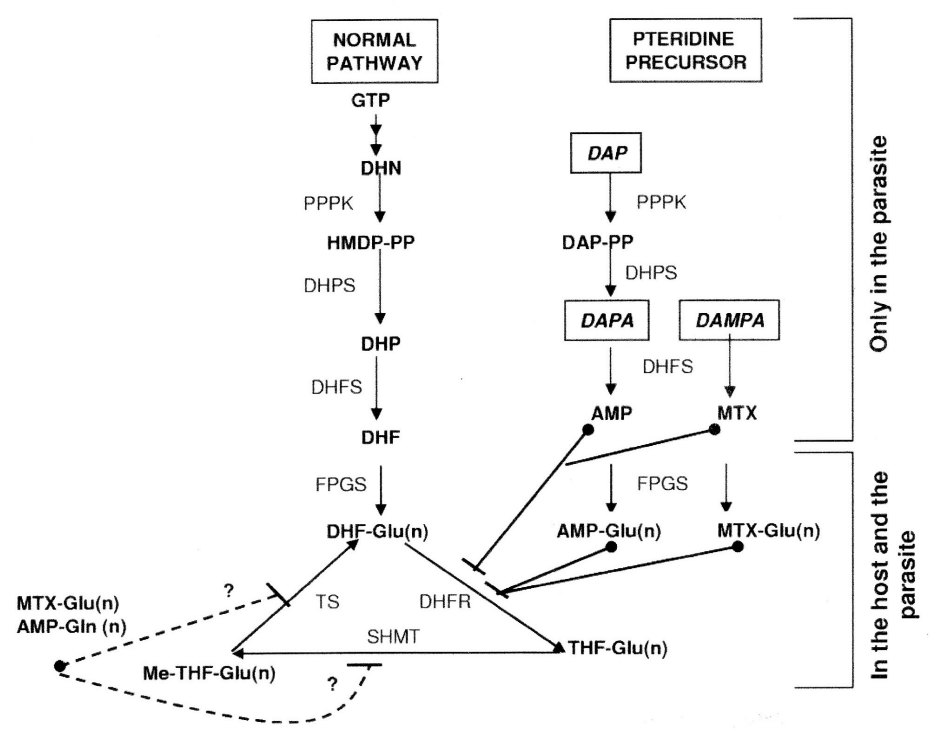

Gambar 4.Jalur Folat dan Mekanisme Kerja pada Plasmodium falciparum, dengan Diaminopteridines Analog dari Folat sebagai Precursor. HMP, hydroxy-methyl-pteridine; HMP-PP, hydroxy-methyl-pteridine pyrophosphate; DHP, dihydropteropteroate; DHF-Glu(n), dihydrofolate polyglutamate; THF Glu(n), tetrahydrofolate polyglutamate; meTHF-Glu(n), methylene-tetrahydrofolate polyglutamate; MTX, methotrexate; AMP, aminopterin; DHNA, dihydroneopterin aldolase; PPPK, dihydroneopterin pyrosphosphokinase; DHFS, dihydrofolate synthase; TS thymidylate synthase; SHMT, serine-hydroxy-methyltransferase (28).

Inhibitor DHFR seperti proguanil mempunyai beberapa fungsi pada terapi, jika digunakan sendiri biasanya menjadi kemoprofilaksis, namun hal ini tidak terjadi pada inhibitor DHPS. Pada terapi malaria inhibitor DHFR dan DHFS dapat dikombinasikan secara bersinergi, misalnya seperti Pyrimethamine dan sulfadoxine (SP) dan pyrimethaminedapsone.

Pirimetamin bekerja dengan menghambat enzim DHFR sehingga parasit tidak mampu membentuk asam tetrahidrofolat. Dengan demikian parasit tidak mampu melanjutkan siklus hidupnya, akhirnya difagosit. Pada parasit $P$. falciparum yang telah mengalami satu kali mutasi pada gen menyebabkan resistensi lebih cepat terjadi. Sulfadoxin bekerja berkompetisi dengan PABA ( para amino benzoic acid) untuk mendapatkan enzim dihidrofolate sintethase (dhfs), sehingga pembentukan asam dihidrofolat terganggu. Dengan demikian asam folat yang diperlukan parasit tidak terbentuk. Resistensi terhadap sulfadoxin karena parasit mampu menggunakan jalur lain sehingga terhindar dari pengaruh sulfadoksin (29).

Resistensi terhadap Inhibitor DHFR dihasilkan dari mutasi yang spesifik dari gen dhfr dalam DHFR. Mutasi pada Ser-108 menjadi Asn-108 merupakan mutasi pertama pada pyrimethamine. Mutasi subsekuen pada Asn-51 menjadi lle-51 dan Cys-59 menjadi Arg-59 mempertinggi tingkat resistensi terhadap obat. Mutasi pada lle-164 menjadi Leu164 akan semakin melengkapi tingginya tingkat resistensi terhadap obat (30). Mutasi dhfr-164 mempunyai frekuensi yang rendah pada isolat Tanzania namun belum begitu je- las apakah dapat memperpanjang dan memperluas penyebaran dari mutasi. Mutasi gen dhps secara in vitro berhubungan dengan kemosensivitas pada sulfonamide. Parasit yang memiliki tingkat mutasinya dua kali akan menyebabkan resistensi yang lebih tinggi (31). Hal tersebut akan memicu terjadinya mutasi pada dhps yang lain, dan mengubah ser-436 menjadi Ala-613. Pada mutasi tunggal dapat mempengaruhi Ala-581. Kombinasi mutasi pada dhfr dan dhps akan menyebabkan kegagalan pengobatan pada kasus klinis (32). Melalui uji coba pada urutan gen pfdhfr menunjukkan parasit yang resisten memiliki kemampuan menyebar menjadi luar biasa (33).

\section{Obat Antimalaria yang Bekerja sebagai Pengantar Proses Alkilasi (Qinghaosu Artemisinin)}

Qinghaosu merupakan obat antimalaria golongan seskuiterpen lakton yang bersifat skizontosida darah untuk $P$. falciparum dan $P$. vivax. Obat ini merupakan obat tradisional Cina untuk penderita demam yang dibuat dari ekstrak tumbuhan Artemesia annua (qinghao) yang sudah dipakai sejak ribuan tahun lalu. Qinghaosu tidak diberikan pada wanita hamil karena efek toksik (34)

Artemisinin termasuk ke dalam kelompok senyawa seskuiterpen lakton, bukan alkaloid atau amina seperti pada kuinin. Struktur molekul artemisin mengandung jembatan peroksida, diyakini ampuh pada kerja obat dan dapat menginduksi oksidatif stres $(34,37)$. Obat artemisin diketahui bekerja secara spesifik pada tahap eritrositik.

Artemisinin mempunyai 4 derivat yaitu (i) Artemisinin (tablet untuk peroral dan supositoria untuk perektal). (ii) 
Artesunate (tablet untuk peroral dan bubuk kering yang dilarutkan dengan larutan $\mathrm{NaHCO} 35 \%$ untuk pemberian intravena atau intramuskular). (iii) Artemether (larutan minyak dalam kapsul untuk peroral dan dalam ampul untuk pemberian intramuskular), dan (iv) Arteether (dalam larutan ether untuk pemberian intramuskular (8). Obat ini terutama digunakan untuk pengobatan malaria falciparum yang resisten terhadap $\mathrm{CQ}$ atau multidrug dan malaria berat atau dengan komplikasi karena efek obat yang sangat cepat namun toksisitasnya rendah. Dosis yang efektif masih terus diteliti. Tablet Artesunat telah diuji secara klinik pada penderita malaria falciparum tanpa komplikasi di daerah resisten multidrug dengan dosis $600 \mathrm{mg}$ dalam 5 hari yaitu $100 \mathrm{mg}$ tiap 12 jam pada hari 1, kemudian dilanjutkan $50 \mathrm{mg}$ tiap 12 jam pada 4 hari berikutnya. Sampai dengan hari ke 14 angka kesembuhan mencapai $100 \%$ kemudian menjadi $75 \%$ pada hari ke 28 , dengan waktu bebas panas dan waktu bebas parasit yang dibutuhkan adalah 14,0 \pm 4,6 jam dan $32,0 \pm 5,9$ jam. Tidak ditemukan efek samping secara klinis laboratoris (35). Parenteral intravena artesunat sedang diteliti pada penderita malaria berat dengan dosis $1,2 \mathrm{mg} /$ $\mathrm{kgbb}$, diberikan pada 0, 4, 24, dan 48 jam (3 hari) sehingga dosis total mencapai 240 - $300 \mathrm{mg} \mathrm{(36).}$

Struktur jembatan peroksida pada molekul artemisin diputus oleh ion $\mathrm{Fe} 2+$ (ion $\mathrm{Fe}$ ini) menjadi radikal bebas yang sangat reaktif. Radikal-radikal artemisin ini kemudian menghambat dan memodifikasi berbagai macam molekul dalam parasit, sehingga parasitnya mati. Seperti diketahui bahwa sumber ion $\mathrm{Fe} 2+$ intrasel adalah heme (komponen penting dalam hemoglobin). Oleh karena itu maka Fe2+ bertanggung jawab untuk mengaktifkan artemisin untuk membunuh parasit. Pada metabolisme parasit dalam sel darah merah, parasit memakan dan menghancurkan sampai $80 \%$ sel hemoglobin inang pada FV. Selanjutnya akan melepaskan $\mathrm{Fe} 2+$ heme, lalu teroksidasi menjadi Fe3+ hematin, kemudian mengendap dalam FV membentuk kristal disebut hemozoin $(33,37)$.

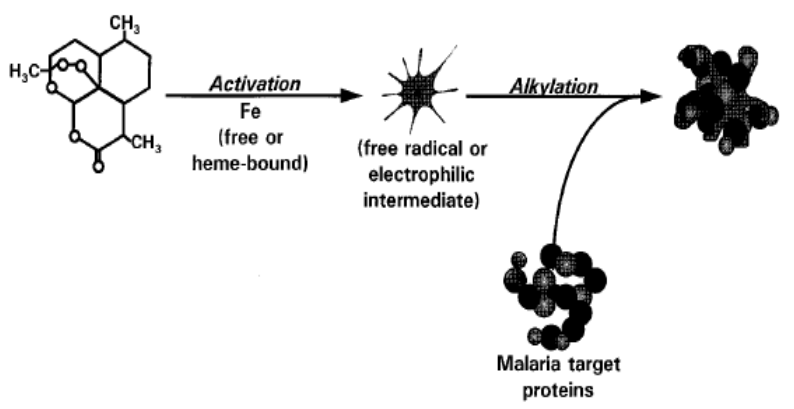

Gambar 5. Mekanisme Kerja Artemisin

Keterangan:

Tahap 1. Komponen artemisin diaktivasi oleh heme atau molekul $\mathrm{Fe}$ untuk memproduksi radikal bebas dan elektrofilik (alkilasi) intermediet. Tahap 2. Reaksi spesies yang reaktif diikuti perusakan pada membran spesifik dari parasit malaria yang terhubung dengan protein (33).
Dengan demikian mekanisme artemisin dan derivatnya dilakukan oleh generasi radikal bebas dari obat-obatan tersebut dengan melalui dua tahap (i) menghasilkan radikal bebas dengan atom $\mathrm{C}$ di tengah. (ii) Menuju target protein yang spesifik (38).

Artemisinin dan dihidroartemisinin memiliki kemampuan untuk berakumulasi dengan eritrosit terinfeksi namun hubungannya dengan konsentrasi plasma di eritrosit belum diketahui (39). Target untuk artemisinin telah diketahui (PfATPase6), namun studi sebelumnya belum menghubungkan polimorfisme gen yang mengkode enzim ini apakah dapat menurunkan kerentanannya $(40,41)$.
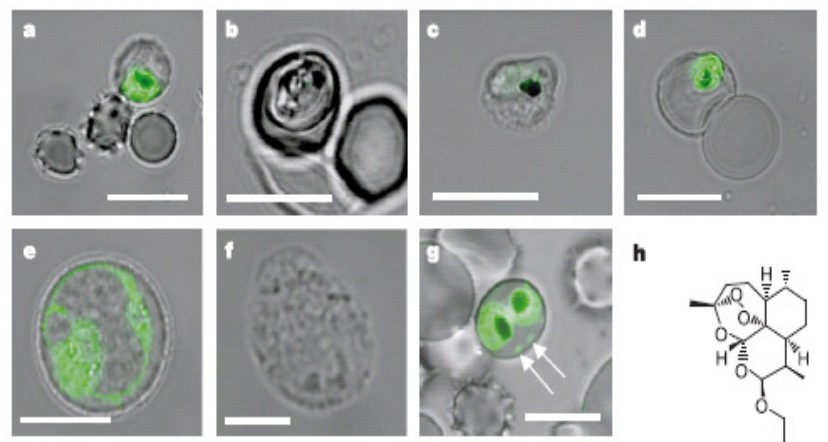

h
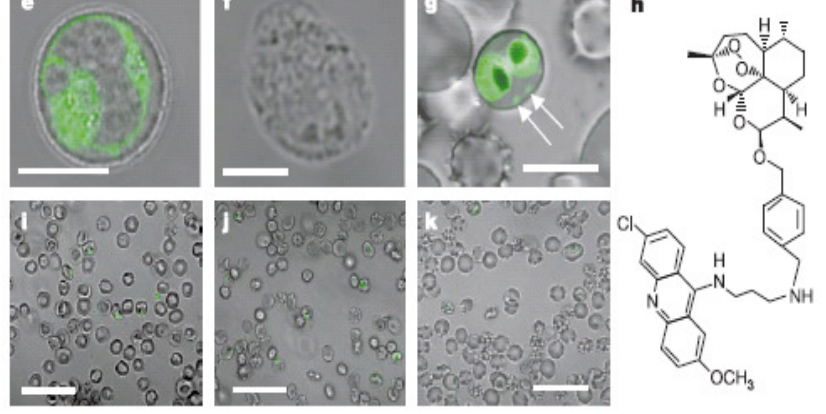

Gambar 6.Interaksi Parasit dengan Artemisin dan PfATP6.

Penggunaan artemisin yang dilabel dengan molekul pendar hijau menunjukkan bahwa molekul artemisin tersebar ke seluruh bagian sel parasit dan tidak terlokalisasi dalam FV. Jadi bukan seperti pada obat antimalaria $C Q$ yang bekerja melalui pengikatan hem, aktivitas artemisinin tidak memerlukan hem (40).

Artemisin bekerja melalui penghambatan enzim ATPase bergantung kalsium (PfATP6). PfATP6 mirip dengan ATPase mamalia sarcoplasmic endoplasmic reticulum calcium ATPase (SERCA) yang terletak dalam kompartemen intrasel terbungkus membran yang disebut retikulum endoplasma/sarco. Pada parasit, kompartemen ini tersebar luas dalam sitoplasma di luar FV parasit. Artemisin yang terbungkus di dalam gelembung membran diangkut dari sel darah merah ke dalam parasit. Setelah dalam parasit, artemisin diaktifkan oleh ion $\mathrm{Fe} 2+$ atau prosesproses yang bergantung Fe lain dekat dengan PfATP6 dalam retikulum endoplasma (42).

\section{Pencegahan Resistensi dengan Kombinasi Obat Antimalaria}

Teori yang mendasari penggunaan obat kombinasi untuk tuberkulosis, leprosi, dan penularan HIV sudah dikenal. Sekarang digunakan untuk malaria (43). 
White menyatakan bahwa proses pengobatan yang tidak lengkap juga merupakan salah satu penyebab Plasmodium menjadi kebal. Selain penggunaan obat anti malaria yang tidak tepat dan benar, variabel lain yang juga berpengaruh dalam meningkatkan kekebalan Plasmodium misalnya karakteristik dari Plasmodium itu sendiri. Parasit malaria ini secara genetik sangat beragam, beberapa galur tertentu dapat menghadapi obat-obatan antimalaria tanpa mengganggu fungsi tubuh ataupun mematikan dirinya. Galur "sakti" ini dapat mewariskan kemampuan kekebalan tersebut pada keturunannya. Selain itu, galur yang kebal akan mendominasi jenis parasit yang ada. Kekebalan parasit malaria umumnya terjadi jika obat yang digunakan hanya satu jenis saja (5).

Pengobatan kombinasi dilakukan bila sudah ada studi tentang pola resistensi di suatu daerah melalui survei resistensi. Bila suatu obat sudah mengalami resistensi $>$ $25 \%$ maka obat tersebut dianjurkan untuk tidak digunakan. Tujuan dari terapi kombinasi adalah untuk meningkatkan efikasi antimalaria maupun aktivitas sinergestik antimalaria dan memperlambat progresifitas resistensi parasit terhadap obat antimalaria yang baru (9).

Proses pengobatan kombinasi dapat menggunakan lebih dari satu macam obat antimalaria yang bersifat shizontosida darah. Obat ini dapat dalam bentuk formulasi atau gabungan, yang mekanisme kerjanya bebas namun target biokimianya berbeda pada parasit malaria. Apabila komponen obat yang dikombinasikan tidak mempunyai efek skizontosida darah dianggap bukan terapi kombinasi (8).

Obat yang dikombinasi kerjanya saling berinteraksi. Seperti penelitian baru-baru ini menggambarkan daerah interdomain pada DHFR-TS dapat menurunkan dTMP plasmodial yang tersedia juga dapat menyebabkan terjadinya penurunan potensiasi dari antifolat (44). Penghambatan yang kuat dapat terjadi pada jalur metabolisme dari antimalaria seperti DHFR/DHPS. Contoh lain yang dapat bersinergi adalah kombinasi proguanil dengan naphthoquinone menoctone. Monoctone dipercaya mempunyai dua mekanisme melawan parasit malaria. Pertama adalah sebagai penghambat yang kuat dari dehidrogenase dihydroorotate, melalui penghambatan dihydroorotate dari uridina monophosphate sintese. Kedua dikombinasikan dengan proguanil, terjadi kompetisi dengan ubikuinon selama oksidasi dari tetrahydrofolate (45). Sebaliknya mekanisme sinergis pada biguanida proguanil, sifatnya dapat mencegah pertumbuhan P.falciparum dan dalam metabolisme cycloguanil membebaskan DHFR. (46), (47) Untuk mencegah kemungkinan adanya kekebalan parasit malaria terhadap obat antimalaria, WHO menghimbau beberapa negara agar hanya menggunakan Artemisinin Combination Therapy (ACT) yang telah disetujui $\mathrm{WHO}$, yaitu artemisinin yang dikombinasikan dengan amodiaquine, lumefantrine, mefloquine atau SP dengan kualitas terbaik. Selain itu juga diperlukan adanya pemberitahuan secara intensif kepada masyarakat pengguna ACT agar menjalankan proses pengobatan secara lengkap hingga selesai (48).

\section{Mekanisme kerja pada Arthemisin Combine Therapy (ACT) dengan obat antimalaria lain}

Arthemisin combine therapy (ACT) mempunyai banyak manfaat karena akan memperpanjang waktu resistensi dan mencegah terjadinya resistensi (49). ACT juga dapat mengurangi resiko terjadinya pengulangan gejala klinis 'recrudescence' (50).

Kombinasi artemisin dan meflokuin pada kasus klinis sangat relevan karena keduanya dapat bersinergi dengan baik pada rasio konsentrasi $<40$. Kombinasi meflokuin dan artemisin secara in vitro dan in vivo dapat bersinergi dengan baik dan sudah digunakan pada kasus klinis di Thailand dengan parasit yang MDR (51).

Beberapa derivat semisintetis dari artemisin contohnya artemether, arteether, dan artesunate, merupakan ramuan aktif dari tanaman qinghao sebagai agen aktif yang utama di dalam tubuh karena mampu memetabolisme dihydroartemisinin. Obat ini dapat bertindak cepat melawan gametosit parasit pada fase seksual (10).

Pada pertengahan siklus hidup pendek, derivative semisynthetis, dan derivat metabolit dihydroartemisinin dosis tunggal mengharuskan perawatan 5-7 hari atau lebih. Pengobatan dengan kombinasi dapat mengurangi waktu paruh obat yang panjang sehingga dapat mempercepat kesembuhan (10). Derivat artemisin yang dikombinasikan dapat menurunkan perkembangan resistensi dari parasit (4, 52). Di Thailand penggunaan kombinasi artesunat dengan mefloquin direkomendasikan karena dapat digunakan pada situasi epidemiologi yang berbeda $(10,53)$.

Secara universal pendekatan aplikabilitas dan kepraktisan menjadi perhatian secara penuh terutama di Africa (54). WHO melaporkan ada tiga masalah penting yang muncul. Pertama mengapa penggunaan komponen kombinasi dari artemisin harus mempunyai waktu paruh yang lebih panjang? Kemungkinan penggunaan salah satu dari mitra kombinasi tersebut pada daerah yang luas dengan transmisi yang kuat tidak cocok, karena waktu paruh yang terlalu panjang, namun dengan penggunaan bersama derivat artemisin, parasit dapat dibersihkan dari sirkulasi lebih cepat sehingga perkembangan parasit kearah yang resisten dapat dihambat. Kedua pengobatan harus dapat menjangkau penderita yang miskin. Pengembangan komponen kombinasi yang dilakukan dengan campuran dua atau lebih bahan aktif dalam suatu tablet dapat mengurangi masalah ini. Ketiga relatif murah tetapi terstandart sebagai obat kombinasi. Meski murah oleh dari patokan-patokan internasional, derivat artemisinin tetap lebih mahal dibanding antimalarial tradisional seperti $C Q$ dan sulphadoxine/pyrimethamine, namun tidak semua kom- 
ponen obat selain artemisin yang dikombinasi potensial untuk melindungi parasit yang resisten (9).

Sinergi pada terapi kombinasi dengan artemisin terjadi melalui beberapa faktor (i) diyakini bahwa heme atau heme polimerase pada FV merupakan target dari derivat kuinolin (55) dilaporkan bahwa artemisin juga, bereaksi dengan hemin di dalam $F V(56)$ (ii) kombinasi meflokuin dan artemisin dengan affinitas yang tinggi akan mengikat membran pospolipid. Dengan demikian kombinasi artemisin dan meflokuin akan berinteraksi dengan membran parasit lebih tinggi / meningkat (49).

Kombinasi terapi yang lain dari kelompok kuinolin metanol yaitu kuinin dan meflokuin. Keduanya bersinergi aktif dengan artemisin, namun bukan untuk semua komponen dari kuinolin metanol. Hal serupa ditemukan bahwa artemisin juga dapat bersinergi dengan komponen obat antimalaria dari kelompok 2 amino aril alkohol (50).

\section{KESIMPULAN}

1. Resistensi terhadap obat antimalaria terjadi karena beberapa faktor terutama : faktor genetik (mutasi gen) dari Plasmodium falciparum. Jalur mekanisme resistensi lokasinya berbeda, karena target kerja obat yang berbeda.

2. Resistensi obat antimalaria berhubungan dengan produk-produk gen parasit dan posisi mutasi pada alela resisten

3. Mekanisme terapi kombinasi artemisin dengan obat antimalaria lain terjadi melalui beberapa faktor. Kombinasi meflokuin dan artemisin mempunyai affinitas yang tinggi untuk mengikat membran pospolipid dari parasit.

\section{DAFTAR KEPUSTAKAAN}

1. Talisuna AO, Bloland P and Alessandro AB. History, Dynamics,and Public Health Importance of Malaria Parasite Resistance. Am. Soc. For Micro. 2004; (17) 1: 235-254.

2. Olliaro PL and Bloland PB. Clinical and public health implications of antimalarial drug resistance. In Antimalarial Chemotherapy: Mechanisms of Action, Resistance, and New Directions in Drug Discovery (ed. P. J. Rosenthal) Totowa, NJ: Humana Press. 2001; 65-83.

3. Wellem TE \& Plowe CV. Chloroquine Resistant Malaria. J. Infect. Dis. 2001; 184: 770-776.

4. White NJ. Delaying Antimalarial Drug Resistance with Combination Chemotherapy. Parasitologia 1999; 41: 301-308.

5. White NJ. Antimalarial Drug Resistance. The Journal of Clin. Inves. 2004; 113: 1084-1092.

6. Rathod PK, McErlean T and Lee PC. Variations in Frequencies of Drug Resistance in Plasmodium falciparum. USA: Proc. Natl Acad. Sci. 1997; 94: 9389-9393.

7. World Health Organization. Antimalarial drug Combination Therapy. Report of a WHO Technical Consultation. WHO/CDS/RBM/2001.35.Geneva, Switzerland: World Health Organization

8. Winstanley P, Ward S, Snow R, \& Breckenridge A. Therapy of Falciparum Malaria in Sub-Saharan Africa: from Molecule to Policy. Am. Soc for Microbiol 2004; 17(3): 612-637.

9. Rosenthal PJ. Antimalarial Drug Discovery: Old and New Aproach. The J. of Exp. Biol. 2003; 206: 3735-3744.

10. Ridley RG. Medical Need, Scientific Opportunity and the Drive for Antimalarial Drugs. Nature 2002; 415: 686-693.

11. Foster SDF. Pricing, Distribution and Use Antimalarial Drugs. Bulls. WHO. 1991; 69: 349-361.

12. Ginsburg H, Famin O, Zhang J, \& Krugliak M. Inhibition of Glutathione-Dependent Degradation of Heme by Klorokuin and Amodiaquine as a Possible Basis for Their Antimalarial Mode of Action. Biochem Pharmacol 1998; 56: 1305-1313.

13. Ginsburg H, Ward SA, \& Bray PG. An Integrated Model of Klorokuin Action. Parasitol Today 1999; 15: 357-360.

14. Liu J, Gluzman IY, Drew ME and Goldberg DE. The Role of Plasmodium falciparum Food Vacuole Plasmepsin. The Journal of Biological chemistry 2005; 280 (2): 1432-1437.

15. Kublin JG, JF Cortese, EM Njunju, RA Mukadama, JJ Wirima, PN Kazembe, AA. Djimde, B Kouriba, and CV Plowe. Reemergence of Chloroquine-Sensitive Plasmodium falciparum Malaria after Cessation of Chloroquine Use in Malawi. J. Infect. Dis. 2003; 187: 1870-1875.

16. Yayon A, R Timberg, S Friedman, and H Ginsburg. Effects of Chloroquine on the Feeding Mechanism of the Intraerythrocytic Malarial Parasite Plasmodium falciparum. J. Protozool 1984; 31: 367-372.

17. Cowman AF, D Galatis, and JK Thompson. Selection for Mefloquine Resistance in Plasmodium falciparum is linked to Amplification of the pfmdr1 Gene and Cross-Resistance to Halofantrine and Quinine. USA: Proc. Natl. Acad. Sci. 1994; 91: 1143-1147.

18. Saliba KJ, Folb PI, \& Smith PJ. Role for the Plasmodium falciparum Digestivevacuole in Klorokuin Resistance. Biochem Pharmacol 1998; 56: 313-320.

19. Kirk K. Membrane Transport in the Malaria Infected Erytrhrocyte. Physiol. Rev. 2001; 81: 495-537. 
20. Hayward R, Saliba KJ \& Kirk K. The $\mathrm{pH}$ of the Digestive Vacuole of Plasmodium falciparum is not Associated with Klorokuin Resistance. Journal of Cell Science 2006; 119: 1016-1025

21. Su X, Kirkman LA, Fujioka H, and Wellems TE. Complex Polymorphisms in an approximately $330 \mathrm{kDa}$ Protein are linked to Chloroquine - Resistant P. falciparum in Southeast Asia and Africa. Cell 1997; 91: 593-603.

22. Plowe CV. Monitoring Antimalarial Drug Resistance: Making the Most of Thetools at Hand. J. Exp. Biol 2003; 206: 3745-3752.

23. Cooper RA, Michael T, Ferdig, Su XZ, Lyann MB. Ursos, Mu J, Nomura T, Fujioka H, Fidock DA, Paul D, Roepe and Wellems TE. Alternative Mutations at Position 76 of the Vacuolar Transmembrane Protein PfCRT Are Associated with Chloroquine Resistance and Unique Stereospecific Quinine and Quinidine Responses in Plasmodium falciparum. Mol Pharmacol 2002; 61: 35-42.

24. Warhurst DC and Path FRC. A Molecular Marker for Chloroquine-Resistant Falciparum Malaria. NEJM 2001; 344:299302.

25. Olliaro PL and Taylor WR. Antimalarial Compounds: from Bench to Bedside. J. Exp Biol 2003; 206: 3753-3759.

26. Nishiyama Y, Okuda Y, Kim H, Huruta T, Kimura M \& Wataya Y. Genetic analysis of mefloquine-resistant mechanism of Plasmodium falciparum. Oxford University Press Nucleic Acids Symposium Series 2004; 48: 163-164.

27. Kim HS, Okuda Y, Begum K, Nagai Y, Wataya Y, Kimura, M, Huruta T. Analysis of pfmdr1 Gene in Mefloquine Resistant Plasmodium falciparum. Nucleic acids Symp. Ser 2001; 1: 231-232.

28. Nduati E, Hunt S, Kamau EM and Nzila A. 2,4-Diaminopteridine-Based Compounds as Precursors for de novo Synthesis of antifolate : Novel class of antimalarial. Am. Soc for Micro. 2005; 49(9): 3652-3657.

29. Kublin JG, F Dzinjalamala, D Kamwendo, E Malkin, J Cortese, L Martino, R Mukadam, S Rogerson, A Lescano, ME Molyneux, PA Winstanley, P Chimpeni, TE Taylor, and CV Plowe. Molecular Markers for Failure of SulfadoxinePyrimethamine and Chlorproguanil-Dapsone Treatment of Plasmodium falciparum Malaria. J. Infect. Dis. 2001; 185: 380-388.

30. Cortese JF, Caraballo A, Contreras CE, and Plowe CV. Origin and Dissemination of Plasmodium falciparum DrugResistance Mutations in South America. J. Infect. Dis. 2002; 186: 999-1006.

31. Plowe CV, JF Cortese, A Djimde, OC Nwanyanwu, WM Watkins, PA Winstanley, JG Estrada-Franco, RE Mollinedo, J C Avila, JL Cespedes, D Carter, and OK Doumbo. Mutations in Plasmodium falciparum Dihydrofolate Reductase and Dihydropteroate Synthase and Epidemiologic Patterns of Pyrimethamine-Sulfadoxine Use and Resistance. J. Infect. Dis. 1997; 176: 1590-1596.

32. Watkins WM, Woodrow C, and Marsh K. Falciparum Malaria: Differential Effects of Antimalarial Drugs on Ex Vivo Parasite Viability during the Critical Early Fase of Therapy. Am. J. Trop. Med. Hyg. 1993; 49:106-112.

33. Bousema JT. Treatment failure of Pyrimethamine-Sulphadoxine and Induction of Plasmodium falciparum Gametocytaemia in Children in Western Kenya. Trop. Med. Int. Health 2003; 8: 427-430.

34. Meshnick SR, Taylor TE, and Kamchonwongpaisan. Artemisin and the Antimalarial Endoperoxides: from Herbal Remedy to Targeted Chemotetherapy. Am. Sos. for Micro 1996; 301-315.

35. Meshnick SR. Artemisinin: Mechanism of Action, Resistance and Toxicity. Int. J. Parasitol 2002; 32: 1955-1660.

36. Giao PT, Binh TG, Kager PA, Long HP, Thang NV, Nam NV and de Vries. Artemisinin for Treatment of Uncomplicated Falciparum Malaria: Is There Place for Monotherapy. Am. J. Trop. Med. Hyg 2001; 65(6): 690-695.

37. Schmuck G, Roehrdanz E, Haynes RK, and Kahl R. Neurotoxic Mode of Action of Artemisinin. Antimicrobial Agents and Chemotherapy 2002; 821-827.

38. Olliaro PL, Haynes RK, Meunier B and Yuthavong Y. Possible Modes of Action nof the Artemisinin Type Compounds. Trends Parasitol 2001; 17: 122-126.

39. Meshnick SR. Free radicals and antioksidant. Lancet 1994; 344:1441-1442.

40. Rath K, Taxis K, Walz G, Gleitter CH, Li Sm and Heide L. Pharmacokinetic Study of Artemisinin after Oral Intake of a Traditional Preparation of Artemisia annua L. (annual wormwood). Am. J. Trop. Med. Hyg. 2004; (70) 2: 128-132.

41. Ludwik UE, Webb RJ, van Goethem ID, East JM, Lee AG, Kimura M, Neil PM, Bray PG, Ward SA and Krishna S. Artemisinins target the SERCA of Plasmodium falciparum. Nature 2003; 424: 957-961.

42. Price RN. Mefloquine Resistance in Plasmodium falciparum Results from Increased pfmdr1 Gene Copy Number. Lancet. In press 2004.

43. Krishna S. Expression and Functional Characterization of a Plasmodium falciparum Ca ${ }^{2+}$-ATPase (PfATP4) Belonging to Subclass Unique to Apicomplexan Organisms. J. Biol. Chem 2001; 276: 10782-10787.

44. Surolia N \& Surolia A. Triclosan Offers Protection against Blood Stages of Malaria by inhibiting enoyl-ACP Reductase of Plasmodium falciparron. Nature Med 2001; 7: 167-173. 
45. Opez-Shirley K, Zhang F, Gosser D, Scott M, and Meshnick SR. Antimalarial Quinones: Redox Potential Dependence of Methemoglobin Formation and Heme Release in Erythrocytes. J Lab Clin Med 194.123:126-130.

46. Slater AF \& Cerami A. Inhibition by Klorokuin of a Novel Haem Polymerase Enzyme Activity in Malaria Trophozoites. Nature 1992; 355: 167-169.

47. Meshnick SR, A Thomas, A Ranz, CM Xu, and HZ Pan. Artemisinin (qinghaosu): the Role of Intracellular Hemin in its Mechanism of Antimalarial Action. Mol. Biochem. Parasitol 1991; 49:181-189.

48. White T, Clode S, Ward S, Gaunt I, Powell C and Clark R. Developmental Toxicity of the Antimalarial Artesunate in Rats and Rabbit. Birth Defects. Res. Part A Clin. Mol. Teratol 2004; 70: 265.

49. Woodrow CJ, Haynes RK and Krishna S. Artemisinins. Postgrad. Med. J. 2005; 81:71-78.

50. Gupta S, Thapar MM, Wernsdorfer WH and Bjorkman A. In vitro Interactions of Artemisinin with Atovaquone, Quinine and Mefloquine against Plasmodium falciparum. Am. Soc. For Microbiolgy 2002; 46 (5): 1510-1515.

51. Ekong R and Warhurst DC. Synergism between Arteether and Mefloquine or Quinine in a Multidrugs Resistant Strain of Plasmodium falciparum In Vitro. Trans. R. Soc. Trop. Med. Hyg. 1990; 84:757-758.

52. Fidock DA and Wellems TE. Transformation with Human Dihydrofolate Reductase Renders Malaria Parasites Insensitive to WR99210 but does not Affect the Intrinsic Activity of Proguanil. USA: Proc Natl Acad Sci; 1997; 197. 94:10931-10936.

53. Uvaniyama J, Chitnumsub P, Kamchonwongpaisan S, Vanichtanankul J, Sirawaraporn W, Taylor P, Walkinshaw MD, and Yuthavong Y. Insights Into Antifolate Resistance from Malarial DHFR-TS Structures. Nat Struct Biol 2003; 10: 357365.

54. Kurosawa Y. et al. Hematin Polymerization Assay as a High-Throughput Screen for Identification of New Antimalarial Pharmacophores. Anlimicmb. Agents Chemother 2000; 44: 2638-2644.

55. Kaneko A, Bergqvist Y, Takechi M, Kalkoa M, Kaneko O, Kobayakawa T, Ishizaki T, and Bjorkman A. Intrinsic Efficacy of Proguanil Against Falciparum and Vivax Malaria Independent of the Metabolite Cycloguanil. J Infect Dis 1999; 179: 974-979.

56. White N. Assessment of the Pharmacodynamic Properties of Antimalarial Drugs in Vivo. Antimicrob. Agents Chemoth 1997; 41:1413-1422. 